treatment of relapse of chronic hepatitis C. International hepatitis inter ventional therapy group. N Engl J Med 1998;339:1493-9.

20 Easterbrook PJ, Berlin JA, Gopalan R, Matthews DR. Publication bias in clinical research. Lancet 1991;337:867-72.

21 Scherer RW, Langenberg P. Full publication of results initially presented in abstracts [systematic review]. Cochrane Library. Issue 2. Oxford: Update Software, 2001.

22 Marcellin P, Boyer N, Gervais A, Martinot M, Pouteau M, Castelnau C, et al. Long-term histologic improvement and loss of detectable intrahepatic HCV RNA in patients with chronic hepatitis $\mathrm{C}$ and sustained response to interferon-alpha therapy. Ann Intern Med 1997;127:875-81.

23 Shiratori Y, Imazeki F, Moriyama M, Yano M, Arakawa Y, Yokosuka O, et al. Histologic improvement of fibrosis in patients with hepatitis $\mathrm{C}$ who have sustained respr 2000;132:517-24.

24 Poynard T, McHutchison J, Davis GL, Esteban-Mur R, Goodman Z, Bedossa $\mathrm{P}$, et al. Impact of interferon alfa- $2 \mathrm{~b}$ and ribavirin on progression of liver fibrosis in patients with chronic hepatitis C. Hepatology 2000;32:1131-7.

25 McHutchison JG, Gordon SC, Schiff ER, Shiffman ML, Lee WM, Rustgi $\mathrm{VK}$, et al. Interferon alfa-2b alone or in combination with ribavirin as initial treatment for chronic hepatitis C. Hepatitis Interventional Therapy Group. N Engl J Med 1998;339:1483-92.

26 Poynard T, Marcellin P, Lee SS, Niederau C, Minuk GS, Idéo G, et al. Randomised trial of interferon alpha2b plus ribavirin for 48 weeks or for 24 weeks versus interferon alpha2b plus placebo for 48 weeks for treatment of chronic infection with hepatitis C virus. International Hepatitis Interventional Therapy Group (IHIT). Lancet 1998;352:1426-32.

27 Koretz RL. Decisions, decisions, decisions. Gastroenterology 2000;118: 1268-70.

28 Pagliaro L, Peri V, Linea C, Camma C, Giunta M, Magrin S. Natural history of chronic hepatitis C. Ital J Gastroenterol Hepatol 1999;31:28-44.

29 Sheperd J, Waugh N, Hewitson P. Combination therapy (interferon alfa and ribavirin) in the treatment of chronic hepatitis $\mathrm{C}$ : a rapid and systematic review. Health Technol Assess 2000;4:1-78.

30 Cummings J, Lee SM, West ES, Cid-Ruzafa J, Fein SG, Aoki Y, et al. Interferon and ribavirin vs interferon alone in the re-treatment of chronic hepatitis C previously nonresponsive to interferon. A meta-analysis of randomised trials. JAMA 2001;285:193-9.

31 Schalm SW, Weiland O, Hansen BE, Milella M, Lai MY, Hollander A, et al. Interferon-ribavirin for chronic hepatitis $\mathrm{C}$ with and without cirrhosis: analysis of individual patient data of six controlled trials. Eurohep study group for viral hepatitis. Gastroenterology 1999;117:408-13.

32 Zeuzem S, Feinman SV, Rasenack J, Heathcote EJ, Lai MY, Gane E, et al. Peginterferon alfa-2a in patients with chronic hepatitis C. $N$ Engl J Med 2000;343:1666-72.

33 Brillanti S, Levantesi F, Masi L, Foli M, Bolondi L. Triple antiviral therapy as a new option for patients with interferon nonresponsive chronic hepatitis C. Hepatology 2000;32:630-4.

(Accepted 23 July 2001)

\title{
Unwanted caesarean sections among public and private patients in Brazil: prospective study
}

\author{
Joseph E Potter, Elza Berquó, Ignez H O Perpétuo, Ondina Fachel Leal, Kristine Hopkins, \\ Marta Rovery Souza, Maria Célia de Carvalho Formiga
}

\begin{abstract}
Objective To assess and compare the preferences of pregnant women in the public and private sector regarding delivery in Brazil.

Design Face to face structured interviews with women who were interviewed early in pregnancy, about one month before the due date, and about one month post partum.

Setting Four cities in Brazil.

Participants 1612 pregnant women: 1093 public patients and 519 private patients.

Main outcome measures Rates of delivery by caesarean section in public and private institutions; women's preferences for delivery; timing of decision to perform caesarean section.

Results 1136 women completed all three interviews; 476 women were lost to follow up (376 public patients and 100 private patients). Despite large differences in the rates of caesarean section in the two sectors (222/717 (31\%) among public patients and 302/419 (72\%) among private patients) there were no significant differences in preferences between the two groups. In both antenatal interviews, $70-80 \%$ in both sectors said they would prefer to deliver vaginally. In a large proportion of cases $(237 / 502)$ caesarean delivery was decided on before admission: 48/207 (23\%) in women in the public sector and 189/295 (64\%) in women in the private sector.

Conclusions The large difference in the rates of caesarean sections in women in the public and private sectors is due to more unwanted caesarean sections among private patients rather than to a difference in preferences for delivery. High or rising rates of
\end{abstract}

caesarean sections do not necessarily reflect demand for surgical delivery.

\section{Introduction}

Different rates of caesarean section in public and private patients suggest that non-medical factors, such as economic gain and pressures of private practice, may motivate doctors to perform surgical deliveries. Alternatively, these differences may reflect patients' preferences and result from informed choices about type of delivery. ${ }^{1-6}$ In Brazil, choosing between these interpretations is contentious as the rate of caesarean sections among private patients is extremely high and more than twice the rate in the public sector. About one quarter of all deliveries take place in the private sector, and more than $70 \%$ of those are by caesarean section. ${ }^{78}$ Such a rate cannot be attributed to the actions of a fraction of the obstetricians with private practice $^{910}$ or the prevalence in the population of the usual medical indications for caesarean delivery. ${ }^{11}$ The most doctor friendly, but still problematic, explanation is a strong preference for surgical deliveries among the upper and middle class women who are most likely to have private medical insurance. ${ }^{12}$

Brazil is often portrayed as a country where there is an unusually large demand for caesarean sections, especially among more affluent women. ${ }^{13}$ The alleged motivations for the choice include fear of vaginal birth, preservation of coital function, relief from the pain of labour, and to obtain a tubal ligation. ${ }^{14}{ }^{15}$ Often the evidence put forward comes from physicians' accounts of women's preferences rather than directly from women themselves. ${ }^{16-18}$ In two recent postpartum studies conducted in Brazil among both private and public
See also editorial by Johanson and Newburn

University of Texas at Austin, Population Research Center, 1800 Main Building, Austin, TX 78712, USA Joseph E Potter professor Kristine Hopkins research associate

University of Campinas, Nucleus for Population Studies, Caixa Postal 6166, Campinas, SP 13081-970, Brazil Elza Berquó professor Marta Rovery Souza researcher

Federal University of Minas Gerais, CEDEPLAR, 832 Rua Curitiba, MC 30170-120, Brazil Ignez $\mathrm{H} \mathrm{O}$

Perpétuo

professor

continued over

BMJ 2001;323:1155-8 
Federal University of Rio Grande do Sul, Postgraduate

Program in Social

Anthropology,

Avenue Bento

Goncalves 9500,

Porto Alegre, RS

91509-500, Brazil

Ondina Fachel Leal professor

Federal University of Rio Grande do

Norte, Department of Statistics, Caixa Postal 1615, Natal, RN 59072-970,

Brazil

Maria Célia de

Carvalho Formiga

researcher

Correspondence to:

J Potter

joe@prc.utexas.edu

Table 1 Baseline characteristics of respondents in final sample and of those lost to follow up, by sector

\begin{tabular}{|c|c|c|c|c|c|c|}
\hline & & Public & & & Private & \\
\hline & Final sample & Lost to follow up & P value* & Final sample & Lost to follow up & $P$ value* \\
\hline No of women & 717 & 376 & & 419 & 100 & \\
\hline Age (years) & 25.3 & 25.4 & 0.919 & 28.7 & 28.3 & 0.569 \\
\hline No of previous deliveries & 0.95 & 1.14 & 0.016 & 0.60 & 0.56 & 0.630 \\
\hline Education (years) & 7.62 & 6.64 & $<0.001$ & 11.0 & 11.1 & 0.730 \\
\hline No of antenatal visits & 1.26 & 1.11 & 0.003 & 1.97 & 1.96 & 0.898 \\
\hline Married/cohabiting (\%) & $596(83.1)$ & $322(85.6)$ & 0.272 & $374(89.2)$ & $88(88.0)$ & 0.771 \\
\hline Preferred vaginal delivery (\%) & $571(79.6)$ & $281(74.7)$ & 0.070 & $303(72.3)$ & $70(70.0)$ & 0.644 \\
\hline
\end{tabular}

*Based on independent samples $t$ test (two tailed, equal variances not assumed) and Pearson $\chi^{2}$.

patients in three metropolitan areas, little evidence of such beliefs was found, and many of the women who had a caesarean delivery declared that they had wanted to deliver vaginally. ${ }^{19} 20$

To gain a more complete assessment of the evolution of women's preferences regarding type of delivery among both public and private patients, we carried out a prospective study to assess these preferences early and late in pregnancy and then compared preferences with outcomes.

\section{Methods}

Participants

We recruited pregnant women aged 18 to 40 years in four cities (Porto Alegre, Belo Horizonte, and Natal, and the municipality of Sao Paulo) in four Brazilian states between April 1998 and June 1999. All women signed informed consent forms. We excluded women who received their antenatal care in specialised clinics (such as clinics for women at high risk, those whose pregnancy was a result of assisted reproduction, and any who were infected with HIV). The women were up to 22 weeks pregnant and had had no more than two antenatal visits before the first study interview. We stratified the sample by sector of care and birth order. In each city we selected a representative list of about 10 hospitals with maternity services in both the public and private sector and recruited women who planned to deliver in these hospitals.

\section{Procedures}

Each woman was interviewed three times: at the time of recruitment; a month before the expected due date; and a month after the expected due date. We typically conducted the first interview in a healthcare facility and the second antenatal interview and the postpartum interview in the woman's home. Reasons for loss to follow up included women not being at the address given, delivery before the second interview, miscarriage, and neonatal death.

We used a standardised questionnaire for each interview. The two antenatal interviews included the question "What type of delivery would you like to have?" for which the precoded responses were vaginal (normal), caesarean, depends on the doctor's decision, and don't know or undecided. To the open question about her reasons for preferring this type of delivery, we precoded up to two responses in order of importance. We asked if the doctor had already talked to her regarding type of delivery and, if so, what was suggested and why. The first questionnaire also determined type of delivery of any previous births.

In the second interview we requested more detail regarding conversations the woman had with her doctor about the type of delivery. If the doctor had recommended a caesarean, in addition to the reasons given, we asked the respondent if the surgery was already scheduled.

The third interview covered what happened during delivery, who attended and in which hospital, whether the delivery was paid for by the public health insurance system, date and time of admission, whether the labour was spontaneous or induced, and whether any anaesthesia was administered. If the delivery was by caesarean we asked if it was scheduled and, if so, when and for what reason. If the caesarean was not scheduled we asked about the timing of the decision to operate and any reasons for the decision. We also included questions regarding satisfaction with care.

\section{Data analysis}

We classified all women who completed all three interviews as public or private patients according to method of payment. For women lost to follow up we based the classification on the clinic where they had received antenatal care. We consider caesarean deliveries to be unwanted if the woman had declared a preference for vaginal birth in both antenatal interviews. We used Pearson $\chi^{2}$ and $t$ tests to assess significance and both SPSS and Stata (StataCorp, College Station, TX).

\section{Results}

We recruited 1612 women, 1093 public patients and 519 private patients. There were 1136 women in the final sample as 476 women were lost to follow up. Of these, 376 were public patients and 100 were private patients. All three interviews were completed by $717(66 \%)$ women in the public sector and $419(81 \%)$ women in the private sector. Most of the loss to follow up ( 405 women) occurred between the first and second interviews. Table 1 shows details of the groups and differences between the final sample and those lost to follow up.

In the final sample, $90 \%$ (377) of private patients were attended at delivery by a private doctor and 9\% (38) by a staff physician. The corresponding figures for the public patients were $12 \%$ (86) and $85 \%$ (609), with $5 \%$ (36) being attended by midwives or nurses. The rates of caesarean delivery were $31 \%(222 / 707)$ in the public sector and $72 \%(302 / 419)$ in the private sector. In both groups about $3 \%$ of deliveries were forceps deliveries, and $66 \%$ in the public sector and $25 \%$ in the private sector were spontaneous vaginal deliveries.

Among primiparous women in the final sample $90 \%$ (280) in the public sector and $84 \%$ (189) in the private sector declared a preference for a vaginal delivery in the first interview (fig 1). Among multiparous women with no previous caesarean delivery, the preference for a vaginal delivery was over $80 \%$ in the 
first interview in both sectors. Finally, among women with a previous caesarean delivery, over $42 \%$ in both sectors stated a preference for vaginal delivery. There was no significant difference in preferences between the two sectors for any of the three categories.

Table 2 shows that most of the women preferred a vaginal delivery either because recovery is faster or because it is the natural way to deliver. The reasons the respondents who wanted a caesarean gave for their preferences, however, were more diverse. Avoidance of pain and concurrent tubal ligation were often mentioned, and women in the private sector often cited a positive experience with a previous caesarean section. Concern for preservation of coital function was hardly mentioned as a reason for preferring caesarean delivery.

In both sectors stated preferences regarding type of delivery were mostly consistent between the first and the second interview (table 3). A large proportion of women consistently declared preferences for a vaginal delivery. The next largest category comprised women who consistently expressed a preference for a caesarean. Only a small proportion of women changed their preference between the two interviews.

Figure 2 shows how women who had twice declared their preference for a vaginal delivery actually delivered. Compared with women in the public sector,

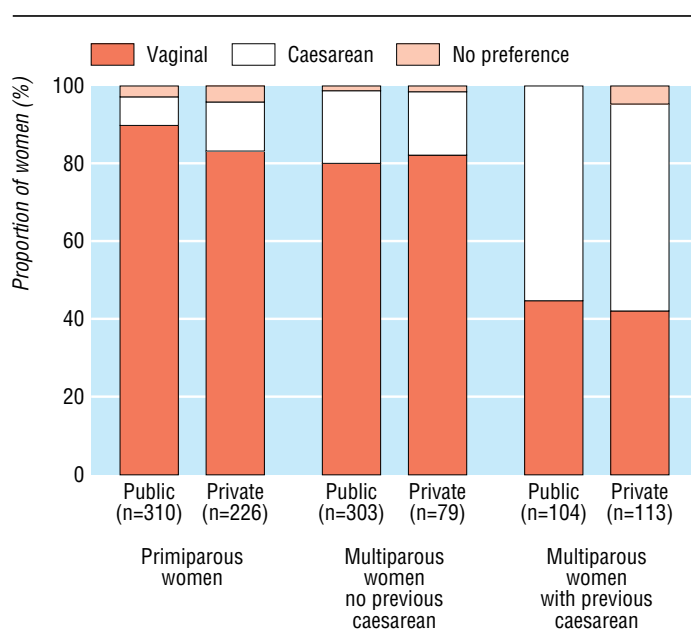

Fig 1 Preference for type of delivery at first interview, according to parity and previous delivery, by sector

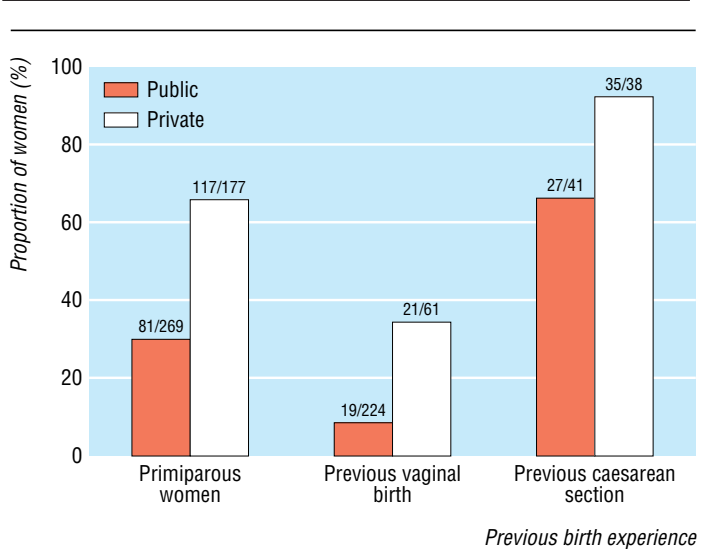

Fig 2 Caesarean section rates for women who preferred vaginal delivery in first and second interviews, by sector, parity, and previous birth experience
Table 2 Reasons given by women for preferring vaginal birth, by sector. Figures are number (percentage) of women

\begin{tabular}{lcc} 
Reason for preference & Public $(\mathbf{n}=\mathbf{5 5 9})$ & Private $(\mathbf{n}=\mathbf{2 9 5})$ \\
\hline Faster recovery & $231(41.3)$ & $127(42.9)$ \\
\hline It is natural & $159(28.4)$ & $109(37.0)$ \\
\hline Better for baby & $25(4.4)$ & $32(10.9)$ \\
\hline Positive experience with previous vaginal delivery & $38(6.8)$ & $6(2.0)$ \\
\hline Other reasons & $107(19.2)$ & $21(7.2)$ \\
\hline
\end{tabular}

Table 3 Women's preferences for method of delivery in first and second interview, by sector. Figures are number (percentage) of women

\begin{tabular}{lcc} 
Preferences (first/second interview) & Public $(\mathbf{n}=6 \mathbf{6 9 7})$ & Private $(\mathbf{n}=\mathbf{3 9 2})$ \\
\hline Vaginal/vaginal & $534(76.6)$ & $276(70.4)$ \\
\hline Caesarean/caesarean & $92(13.2)$ & $75(19.1)$ \\
\hline Vaginal/caesarean & $32(4.6)$ & $19(4.8)$ \\
\hline Caesarean/vaginal & $39(5.6)$ & $22(5.6)$
\end{tabular}

*Excludes 47 women who did not know or had no preference for type of delivery $(2.8 \%$ of public sector sample and $6.4 \%$ of private sector sample).

Table 4 Timing of decision to perform caesarean delivery, by sector. Figures are number (percentage) of women ${ }^{\star}$

\begin{tabular}{lcc} 
Timing of decision & Public $(\mathbf{n}=\mathbf{2 0 7})$ & Private $(\mathbf{n}=\mathbf{2 9 5})$ \\
\hline Scheduled before admission: & & \\
\hline$>24$ hours & $38(18.4)$ & $120(40.7)$ \\
\hline$\leqslant 24$ hours & $10(4.8)$ & $69(23.4)$ \\
\hline Decision taken after admission: & & $89(30.2)$ \\
\hline$\leqslant 6$ hours & $93(44.9)$ & $17(5.8)$ \\
\hline$\geqslant 7$ hours & $66(31.9)$ &
\end{tabular}

*Excludes 22 missing cases: seven from private sector and 15 from public sector. a much larger proportion of women in the private sector subsequently had a caesarean section. All differences between sectors according to parity and previous birth experience were significant $(\mathrm{P}<0.00)$.

Most of the women who consistently expressed a preference for vaginal delivery but actually had a caesarean delivery, over 83\% in both sectors, agreed with the statement that they would have liked to have had a vaginal delivery, but many also agreed with the statement that they were happy to have had a caesarean $(60 \%$ among public patients and $70 \%$ among private patients).

Among the private patients who eventually underwent an unwanted caesarean, $73 \%$ had talked to their doctor about type of delivery by the time of the second interview, but most frequently at their own rather than the doctor's initiative. Only $16 \%$ reported that the doctor had recommended a caesarean section in this conversation. Among the public patients with unwanted caesareans, only $37 \%$ reported a conversation with their doctor regarding type of delivery.

The timing of the decision to have a caesarean delivery differed between public and private patients. Table 4 shows that a much higher proportion of caesarean deliveries were decided on in advance among private than among public patients, and among scheduled caesarean sections more were decided on more than one day in advance among private patients. Similarly, among caesareans that were decided on after admission, the proportion of decisions taken less than six hours after admission was much greater among private patients than it was among public patients.

\section{Discussion}

Although the rates of caesarean section in Brazil are high, especially in the private sector, this is not a reflection of women's preferences for this type of delivery. 


\section{What is already known on this topic}

In Brazil, one quarter of all women deliver in the private sector

The rate of caesarean deliveries in the private sector is extremely high $(70 \%)$ and more than twice that in the public sector, where rates have recently fallen due to a new policy

Previous studies in which women were interviewed after birth showed that a substantial proportion of private patients who have caesarean sections would have preferred normal delivery

\section{What this study adds}

In two antenatal interviews, preferences regarding type of delivery were nearly identical among public and private patients and strongly favoured vaginal births

Contrary to popular belief, middle and upper class women in Brazil do not want to deliver by caesarean section

The main limitation of this study is that, to determine preferences, we had to rely on the answer to a single question (asked twice) regarding the kind of delivery a woman would like to have. Also, there is some inconsistency between preferences expressed in the antenatal interviews and satisfaction with the type of delivery the women actually had. In our view, however, satisfaction after having had a caesarean should not be regarded as an indication of preference for this type of delivery as much as a sign of acceptance of the reasons for the procedure given by the physician. ${ }^{21}$

The large difference in the rates of caesarean section between public and private patients was due to the greater prevalence of unwanted caesarean sections among private patients rather than to a difference in preferences regarding type of delivery. After we accounted for whether the woman had had a previous caesarean section, there was almost no difference in expressed preferences regarding type of delivery between women who received care in the private compared with the public sector. This finding contradicts the assumed belief that middle and upper class Brazilian women prefer caesarean deliveries. ${ }^{13}{ }^{14}$

There are at least three possible interpretations of the large discrepancy between preferences and outcomes among the private patients in this study. Firstly, many Brazilian obstetricians may believe that a caesarean section is actually safer for the newborn and more comfortable than a vaginal delivery for most women. ${ }^{22}$ Secondly, doctors may not have the opportunities or skills needed to elicit their patients' preferences and simply assume that their private patients would prefer a caesarean section. ${ }^{223}{ }^{24}$ Thirdly, scheduled deliveries may be more convenient or the savings in time gained by cutting labour short may motivate obstetricians to choose a caesarean delivery for their private patients. ${ }^{19}$

While we do not have evidence to support any of these interpretations, we are concerned that the rates of caesarean section in the private sector are above any accepted standard and are inconsistent with women's preferences. We hope that our results will encourage change in Brazil and counteract the inclination to interpret high or rising rates of caesarean section elsewhere as evidence of demand for surgical delivery. We have shown that when women's preferences are assessed directly, demand for caesarean sections may be less than expected.

Anibal Faundes (professor of obstetrics, University of Campinas), Carolyn Westhoff (professor of obstetrics/gynaecology and public health, Columbia University), Beverly Winikoff (programme director, Reproductive Health, Population Council), and Marsden Wagner (MD, Washington, DC) read a draft of the paper and made editorial and substantive comments. Susan Rosenthal (professor of psychology and behavioural paediatrics, University of Texas Medical Branch, Galveston) helped with the interpretation.

Contributors: EB, OFL, IHOP, KH, and JEP participated in the conception and design of the study; all authors contributed to drafting the survey questionnaires; JEP wrote the protocol for the National Institute of Health; IHOP wrote the protocol for the United Nations Population Fund. IHOP, MRS, MCdeCF, and OFL supervised data collection in the respective sites (Belo Horizonte, Sao Paulo, Natal, and Porto Alegre). EB, MCdeCF, MRS, IHOP, KH, and JEP participated in the analysis and interpretation of the data. JEP took the lead role in writing the paper. IHOP and $\mathrm{KH}$ contributed to writing and revising the paper. EB, IHOP, and JEP are guarantors.

Funding: The study was supported by grants from the US National Institutes of Health (R01-HD33761) and the United Nations Population Fund, Brazil Office (BRA98/01).

Competing interests: None declared.

1 Murray SF. Relation between private health insurance and high rates of caesarean section in Chile: qualitative and quantitative study. BMJ 2000;321:1501-5.

2 Graham WJ, Hundley V, McCheyne AL, Hall MH, Gurney E, Milne J. An investigation of women's involvement in the decision to deliver by caesarean section. Br J Obstet Gynaecol 1999;106:213-20.

3 Paterson-Brown S, Fisk NM. Caesarean section: every woman's right to choose? Curr Opin Obstet Gynecol 1997;9:351-5.

4 Mould TA, Chong S, Spencer JA, Gallivan S. Women's involvement with the decision preceding their caesarean section and their degree of satisfaction. Br J Obstet Gynaecol 1996;103:1074-7.

5 Roberts CL, Tracy S, Peat B. Rates for obstetric intervention among private and public patients in Australia: population based descriptive study. BMJ 2000;321:137-41.

6 de Regt RH, Minkoff HL, Feldman J, Schwarz RH. Relation of private or clinic care to the cesarean birth rate. N Engl J Med 1986;315:619-24.

7 Badiani R, Ferreira IQ, Ochoa LH, Patarra N, Wong L, Simoes C, et al. Brazil national demographic and health survey, 1996. Rio de Janeiro, Brazil: Sociedade Civil Bem Estar Familiar no Brasil (BEMFAM), 1997:182.

8 Instituto Basiliero de Geografia e Estatica. Pesquisa nacional por amostra de domicílios: sintese de indicadores 1998. Rio de Janeiro: IBGE; 1999.

9 Goyert GL, Bottoms SF, Treadwell MC, Nehra PC. The physician factor in cesarean birth rates. N Engl J Med 1989;320:706-9.

10 Lagrew DC Jr, Adashek JA. Lowering the cesarean section rate in a private hospital: comparison of individual physicians' rates, risk factors, and outcomes. Am J Obstet Gynecol 1998;178:1207-14.

11 Danforth DN. Cesarean section. JAMA 1985.253.811-8.

12 Wagner M. Choosing caesarean section. Lancet 2000;356:1677-80.

13 Quadros LG. Caesarean section controversy. Brazilian obstetricians are pressured to perform caesarean sections. BMJ 2000;320:1073.

14 Faundes A, Cecatti JG. Which policy for caesarian sections in Brazil? An analysis of trends and consequences. Health Policy and Planning 1993;8:33-42.

15 Barros FC, Vaughan JP, Victora CG, Huttly SR. Epidemic of caesarean sections in Brazil. Lancet 1991;338:167-9.

16 Belizán JM, Althabe F, Barros F, Alexander S. Caesarean section controversy. Author's reply. BMJ 2000;320:1074.

17 Berquó E. Brasil, um caso exemplar (anticoncepção e partos cirúrgicos) à espera de uma ação exemplar. Estudos Feministas 1993;1:366-81.

18 Mello e Souza C. C-sections as ideal births: the cultural constructions of beneficence and patients' rights in Brazil. Camb $Q$ Healthe Ethics 1994;3:358-66.

19 Hopkins K. Are Brazilian women really choosing to deliver by cesarean? Soc Sci Med 2000;51:725-40.

20 Perpétuo IHO, Bessa, G.H. de, Fonseca, M.C. Parto cesáreo: uma análise da perspectiva das mulheres de Belo Horizonte. In: XI Encontro Nacional de Estudos Populacionais da ABEP. Caxambu, Brazil: Associaçáo Brasileira de Ensino de Psicologia, 1998.

21 Hemminki E. Cesarean sections: women's choice for giving birth? Birth 1997;24:124-5.

22 Al-Mufti R, McCarthy A, Fisk NM. Obstetricians' personal choice and mode of delivery. Lancet 1996;347:544.

23 Katz J. The silent world of doctor and patient. New York: Free Press, 1984.

24 Green JM, Coupland VA, Kitzinger JV. Expectations, experiences and psychological outcomes of childbirth: a prospective study of 825 women. Birth 1998;17:15-24.

(Accepted 13 September 2001) 